\title{
MEDICO-LEGAL ASPECTS OF OTORHINOLARYNGEAL, FACE AND NECK INJURIES IN UPPER EGYPT: A PROSPECTIVE ANALYSIS AND RETROSPECTIVE EVALUATION OF CLAIMED DISABILITIES
}

\author{
Ghada Ali Omran ${ }^{1}$, Mahmoud Ali Ragaey ${ }^{2}$, Doaa M. EI Shehaby ${ }^{1 *}$ \\ ${ }^{1}$ Department of Forensic Medicine \& Clinical Toxicology \\ ${ }^{2}$ Department of Ear, Nose and Throat (ENT), Faculty of Medicine, \\ Assiut University, Egypt \\ Doaa Mohamed EI Shehaby* (Correspondence author) \\ Contact at: drdoaamoh@yahoo.com
}

Tel:201007361718

\begin{abstract}
Background: Trauma to the ear, nose, throat and face regions is of medicolegal importance as these regions are vulnerable to injury and often associated with mortality and varying degrees of physical, functional and psychological damages. The long-run complications may raise medicolegal claims in the court proceeding. Objectives: to assess the medicolegal aspects of otorhinolaryngeal (ORL) trauma cases alongside a retrospective evaluation of alleged long-term complications or disabilities following those types of injuries. Patient \& Methods: The study included two parts. A descriptive cross-sectional, prospective part included 100 cases of ORL trauma who attended the ENT (Ear, nose and throat) department of Assiut University Hospitals, Upper Egypt during a one-year period. A second retrospective part included all (60) referred cases for ENT consultancy to confirm or deny the medicolegal claims of associated infirmities or disfigurements during the period from 2014 to 2017. Results: The examined presented cases were of mean age $21.43 \pm 12.4$ years with male predominance. Road traffic accidents (RAT) were the main mechanism of injury (44\%) followed by violent assaults $(23 \%)$, fall from a height $(22 \%)$, and lastly firearm injuries $(11 \%)$. Unintentional trauma was the commonest manner for injuries infliction followed by homicidal attacks. The nose was the commonest site of injury followed by ear, then neck and throat regions. Most cases had simple wounds with only one fatal case. Permanent infirmity was expected to be the fate only in $4 \%$ of the presented cases. The retrospective analysis revealed that the patients were of a mean age $41.8 \pm 1.4$ years with male predominance as well. Violent assaults were the commonest cause of claimed disabilities and sensorineural hearing loss was the main reported complication, followed by nasal deformities. False patients' allegations were unexpectedly the highest percentage reported while; true claims were the second common outcome, mainly in cases with nasal deformity. Conclusion: The present study addressed a differential pattern of prospectively presented ORL injuries, and retrospective associated disabilities or long-term complications. Early careful diagnoses and proper treatment can prevent deformity and permanent infirmity following ORL injuries. Further, a good knowledge of the legal implications of ORL associated complications can exclude fabricated claims.
\end{abstract}

Keywords: Facial injuries; nasal fractures; medicolegal; Upper Egypt

\section{INTRODUCTION}

Trauma with all its aspects has great importance, being the main cause of morbidity and mortality with rising frequency worldwide, especially in recent decades. It has been estimated that 16000 people die daily because of trauma (Aremu et al., 2011). Ear, nose, head and 
neck regions are the most common body areas that are involved in injury worldwide as they are mostly exposed and least protected (Adegbiji et al., 2018).

These injuries are often associated with high mortality and varying degrees of physical, functional, psychological damage, cosmetic disfigurement, permanent infirmities and concomitant injuries to other organs that may be added complicating factors (Singhai et al., 2017). Facial injuries involve not only soft tissue and bones, but also by extension, can affect the brain, eyes, neck and mandibles (Gassner et al., 2003).

Road traffic accidents caused by motor vehicles still represent the main cause of ear, nose and throat (ENT) trauma; however, recent reports indicated violence which became another prevalent etiology including homicidal trauma, gunshot or blast injuries, thermal, chemical, electrical burn and suicidal injuries.

A horizontal injury across the face is more dangerous to vital structures than a vertical one as it traverses an extra number of zones. In deep injuries, it is necessary to evaluate the communication with cranial, oral, nasal cavities, and maxillary or fronto-ethmoid sinuses (Gali et al., 2015).

Injuries of the nasal pyramid are of special medicolegal implications. The importance lies in the frequency of injuries, diverse approaches to diagnosis, treatment and possible associated residual deformities that can be involved in later legal proceedings.

The Cartilage of the nose provides both aesthetic and structural support for the mid-face and airway; therefore, proper evaluation and management is necessary to prevent nasal deformity and nasal airway compromise (Pilija et al., 2005). Long term complications of oto-rhino-laryngeal (ORL) injuries and concomitant facial injuries are inevitable in most cases and of legal implications in the court proceedings.

Hence, it is important to be aware of such possible complications in order to provide the best possible early intervention. Long run follow up is essential in determining optimal functional and cosmetic outcomes and detecting any deformity or permanent infirmity (Verbruggen and Halewyck, 2016).

In the developing world, morbidity and mortality associated with ORL injuries remained a significant but an overlooked problem with latent complications that may have latter litigations. Previous studies are still scarce in Egypt especially Upper Egypt though have been prospectively investigated in other developing countries like Tunisia (Bouguila et al., 2008), Nigeria (Aremu et al., 2011) and India (Singhai, et al., 2017).

Egyptian judicial system appoints medicolegal oto-rhino-laryngological consultants to give an expert unbiased technical or scientific opinion in litigations related to either criminal or civil laws (Wasfy et al., 2009). The expert witness may be requested by the police, medicolegal authority or the court to inspect victims of assaults or other claimants to give a detailed medical opinion and report that it is often accepted by the court as documented evidence (Piorkowski, 2001). Usually plaintiffs are seen multiple times after months from the occurrence of primary injury to confirm

associated permanent complication or infirmity. In such cases, initial medical report and diagnostic radiology or audiometry along with careful medical examination, are often requested by the medicolegal consultant (Sanbar, 2007).

\section{AIM OF THE STUDY}

The present study was designed to

1- To assess the medico-legal aspects of Otto-Rhino-Laryngeal trauma cases describing its clinical demographic features, defining its medico-legal criteria (mechanism, mode, and anatomical features)

2- To define their expected sequalae with special emphasis on the medico-legal claims of long run complications and if it was settled in the legal courts. 


\section{METHODOLOGY}

The present work is a descriptive study composed of two parts as follows:

1. A Prospective cross-sectional part:

The present study was carried out on 100 casualties with ORL, face and neck injuries who attended the ENT (Ear, Nose and Throat) clinic and the Trauma Unit of Assiut University Hospitals-that are located in Upper Egypt- during a one year period (from the $1^{\text {st }}$ of June 2017 to the $31^{\text {st }}$ of May 2018). A detailed history was taken from each patient.

Data encompassed demographic information (age, sex, residence, occupation, and education) and medicolegal criteria of their injuries (manner, mechanism, legal type of wound, and expected outcome or infirmity). General and local ENT examinations were carried out for all patients alongside proper investigations such as $\mathrm{x}$-ray films or computed tomography (CT) scan and other diagnostic radiology images. Concomitant other body injuries of such cases were evaluated as well. Casualties were chosen randomly during the specified period with no restrictions of age or sex.

2. A Retrospective part: It included all cases referred for medical consultation with alleged long-term complications or disabilities following oto-rhino-laryngeal injuries during a four years period (2014 through 2017). Victims of assaults were sent by the prosecutor to ENT consultants accompanied by an official request and a litigation file to be examined for an expert witness report. The litigation file contained a preliminary report from the forensic practitioner, the police investigation about the incident and all associated medical records.

Usually, forensic practitioners or prosecutors ask for certain points in the patient's condition to be clarified through the ENT consultant opinion. Reports issued contained a description of the ORL lesion, tools used and whether the lesion conforms to the alleged cause of the incident, and if a permanent infirmity was the outcome. A thorough medical history taking, general and an objective functional ENT examination was carried out. In addition, suitable investigations as X-ray films, ultrasound (US), computed tomography (CT), magnetic resonance imaging (MRI), tympanometry and audiometry for testing hearing loss of different types (sensorineural or conductive hearing loss) and grades, were implemented.

\section{ETHICAL CONSIDERATIONS}

An informed consent was requested from all participants; obtained information was kept confidential for the purpose of scientific research only and the study protocol was approved by the Committee of Medical Ethics, Faculty of Medicine, Assiut University.

\section{STATISTICAL ANALYSIS}

Data were analyzed using IBM SPSS version 22 (SPSS, Inc., Chicago, USA). Results were expressed as frequencies and percentages in qualitative data alongside mean \pm SD for quantitative data. Categorical variables were analyzed using Chi-square test $\left(\chi^{2}\right)$ and Fisher's exact test depending on the size of the data set. $\mathrm{P}$ values $<0.05$ were considered statistically significant.

\section{RESULTS}

1. Prospective part analysis: Assessment of patients presented with ORL, face and neck injuries were undertaken. Figure (1): showed the demographic characteristics of the prospectively examined cases. Young adults (aged 21 to $\leq 30$ years) had the highest incidence of injuries $(30 \%)$. Age range of presented casualties was 2-60 years with a mean of $21.43 \pm 12.4$ years. Male to female ratio was $4: 1$ and nearly equal percentages of patients belonged to urban or rural areas. More than half of cases were jobless (51\%), 31\% were manual workers and $18 \%$ were employees. 


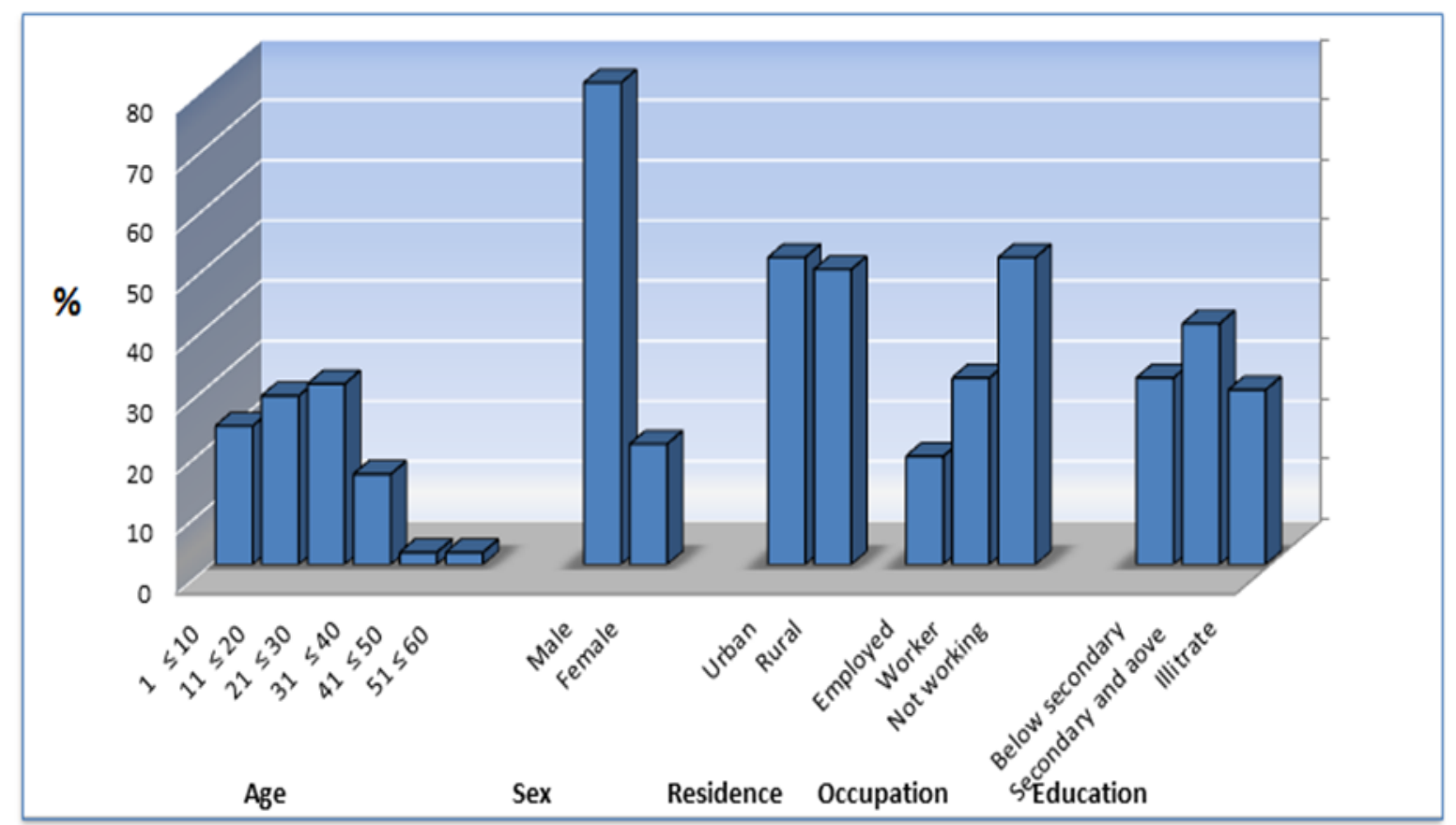

Figure (1): Demographic criteria of ORL trauma cases presented to Assiut University Hospitals (2017/2018).

Figure (2): showed medicolegal criteria of examined causalities. Road traffic accidents were the main mechanism (cause) of injuries (44\%) followed by violent assaults $(23 \%)$ and fall from a height (22\%), while firearm-related injuries were the least recorded (11\%). Blunt instruments were responsible for the majority of cases $(79 \%)$ followed by firearm weapons $(11 \%)$, but sharp instruments were the causative tools in only $10 \%$ of cases. Accidental manner of injury was the commonest followed by homicidal means in about one fifth of injuries (19\%) while $11 \%$ were suicidal. Anatomical features of injuries indicated that the middle face was involved in > half of injuries $(55 \%)$, while injuries in the right and left side of the face were distributed equally $(18 \%)$. The lower third of the face was the least involved (9\%). 


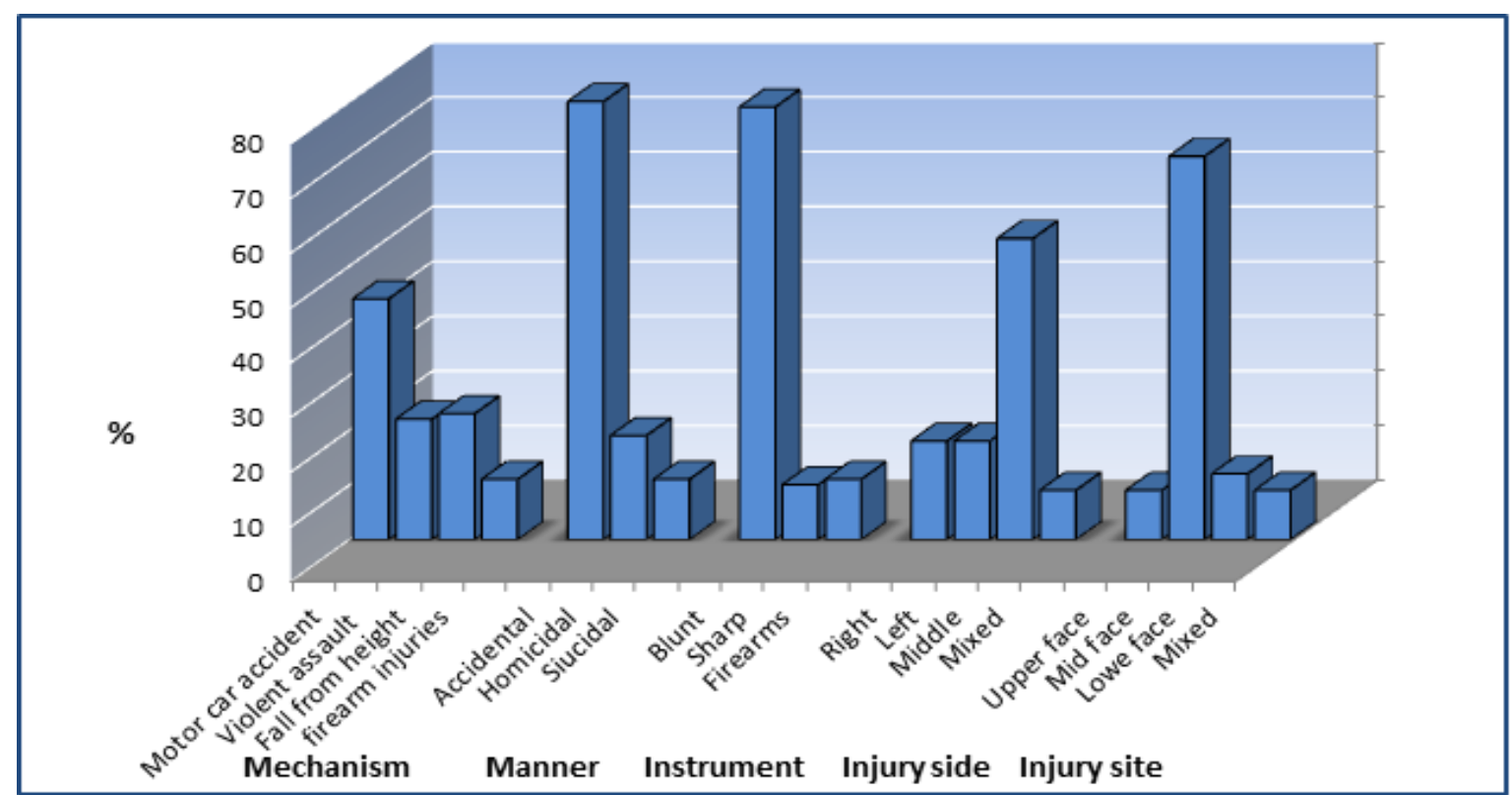

Figure (2): Medicolegal criteria (mechanism, manner, causative instrument, side, and site) of ORL injuries presented to Assiut University Hospitals (2017/2018).

Table (1): showed the pattern of ORL, face and neck injuries in examined casualties. The nose was the commonest target of injuries comprising nearly half of cases $(48 \%)$ followed by the ear (28\%), then isolated facial fractures (19\%), while the neck and throat were the least affected (19\%). Among different patterns of nasal injuries; isolated nasal bone fracture was the most common (35\%), followed by isolated soft nasal tissue injuries $(11 \%)$ and the least was traumatic epistaxis $(2 \%)$.

Ear injuries varied from otorrhea due to fracture temporal bone or skull base fracture (10\%), then bleeding per ear $(9 \%)$. External auditory canal or auricle injuries were minimally observed. Multiple facial bone fractures were the most observed among other facial injuries (13\%). Soft tissue injury of the neck $(6 \%)$ was the prevalent type in neck injuries. Notably, isolated ORL injuries were observed in majority of patients $(79 \%)$, while poly-traumatized patients who suffered other concomitant injuries (extradural hemorrhage, facial palsy, vertebral injury, rib fracture, lower limb fracture) represented about one fifth of cases $(21 \%)$.

According to the Egyptian legal classification of wounds that depends on the expected period of recovery (more or less than 20 days and if accompanied by infirmities); the majority were simple wounds $(73 \%)$, then dangerous wounds (26\%), and only one case suffered a fatal wound. As for the expected outcome, complete recovery was expected by ENT clinician to be the fate in the majority of injured subjects, deformity in $4 \%$, permanent infirmity in $3 \%$ and death was anticipated to be the outcome only in one case. 
Table (1): Patterns, legal types, and expected outcomes of ORL injuries in Assiut University Hospitals (2017/2018)

\begin{tabular}{|c|c|c|}
\hline Character & $\begin{array}{c}\text { Cases }(\%) \\
n=100\end{array}$ & Total \\
\hline \multicolumn{3}{|l|}{ Pattern of Injury } \\
\hline Nose & 35 & 48 \\
\hline Nasal bone fracture & 11 & \\
\hline Soft tissue injury of the nose without nasal fracture & 2 & \\
\hline \multicolumn{3}{|l|}{ Traumatic epistaxis } \\
\hline Ear & 10 & 28 \\
\hline Otorhea (fracture temporal bone or skull base) & 6 & \\
\hline Injury of external auditory canal & 3 & \\
\hline Injury or avulsion of the auricle & 9 & \\
\hline \multicolumn{3}{|l|}{ Bleeding per ear } \\
\hline Sub-mental firearm inlet & 1 & 5 \\
\hline Tear in the soft palate & 1 & \\
\hline Soft tissue injury of the neck & 3 & \\
\hline \multicolumn{3}{|l|}{ Isolated facial injuries } \\
\hline Fracture maxilla & 2 & 19 \\
\hline Fracture mandible & 4 & \\
\hline Multiple facial bones fracture & 13 & \\
\hline \multicolumn{3}{|l|}{ Associated Injuries } \\
\hline Isolated ORL injuries & 79 & \\
\hline $\begin{array}{l}\text { Polytrauma (cases with trauma involve other body parts in addition to head } \\
\& \text { neck trauma) }\end{array}$ & 21 & \\
\hline \multicolumn{3}{|l|}{ Legal type of injury (Expected Period of Recovery) } \\
\hline Simple wound & 73 & \\
\hline Dangerous wound & 26 & \\
\hline Fatal wound & 1 & \\
\hline \multicolumn{3}{|l|}{ Expected final fate } \\
\hline Complete recovery & 92 & \\
\hline Deformity & 4 & \\
\hline Permanent infirmity & 3 & \\
\hline Death & 1 & \\
\hline
\end{tabular}

Table (2): displayed the relationship between mechanism (cause) and manner of ORL injuries. It revealed that majority of motor car accidents were unintentional (97.8\%). Falls from heights were mostly accidental (91\%) with equal distribution in homicidal as well as suicidal manner in remaining cases.
Violent assaults or fights were only homicidally inflicted as expected, but firearm injuries were accidental in (81.8\%). A highly statistically significant relation of different mechanisms of ORL injuries to their manner of infliction was deduced through Chi-square analysis $\mathrm{P}$ value $=$ (0.001). 
Table (2): Relationship between the mechanism and the manner of ORL injuries presented to Assiut University Hospitals (2017/2018)

\begin{tabular}{lcccl}
\hline \multirow{2}{*}{ Mechanism of injury } & \multicolumn{3}{c}{ Manner of ORL injuries } & \\
\cline { 2 - 4 } & $\begin{array}{c}\text { Accidental } \\
(\%)\end{array}$ & $\begin{array}{c}\text { Homicidal } \\
(\%)\end{array}$ & $\begin{array}{c}\text { Suicidal } \\
(\%)\end{array}$ & $X^{2} p$-value \\
\hline Road traffic accident & 97.8 & 2.2 & - & \\
Fall from height & 91 & 4.5 & 4.5 & $<0.001^{* *}$ \\
Violent assault or fight & - & 100 & - & \\
Firearm injury & 81.8 & 18.2 & - & \\
\hline
\end{tabular}

2. Retrospective part analyses

Table (3): indicated demographic characteristics of cases with alleged long run complications or infirmities following ORL injuries in the period from 2014 through 2017. Total number of claimants was 60 with the mean patients' age of $41.8 \pm 1.4$ years (age range 7-71 years). Majority of claims were raised by adult males, from urban areas, manual workers and educated to primary or secondary and above levels (38\% each).

Table (4): represented clinical findings detected by ENT consultant's examination of referred patients who suffered past ORL injuries with alleged associated complications. Violent assaults were the commonest cause (91.7\%), while other types had limited percents like road traffic accident, occupational injuries and medical errors. Regarding pattern or form of ORL sequel discovered by clinical examination and appropriate investigations, sensori-neural hearing loss was the commonest finding (36.7\%), followed by nasal deformity (depressed or deviated nasal bridge) and healed old ear drum tear (18.3\%) for each. However, few cases were devoid of any abnormal clinical or investigational finding (16.7\%).

Conductive deafness was the least diagnosed (10\%). The lawsuit was found as false allegations (malingering) in unexpectedly the majority of cases $(66.7 \%)$, while true allegation was the case in $21.7 \%$ of cases. However, ENT consultants could not confirm the causal relationship of claimed infirmities in another $11.7 \%$ of examined patients. 
Table (3): Relationship between the pattern and the mechanism of ORL injuries presented to Assiut University Hospitals (2017/2018)

\begin{tabular}{|c|c|c|c|c|c|}
\hline \multirow[b]{2}{*}{$\begin{array}{l}\text { Pattern of ORL } \\
\text { injuries }\end{array}$} & \multicolumn{4}{|c|}{ Mechanism of injury } & \multirow{2}{*}{$X^{2}-P$ value } \\
\hline & $\begin{array}{l}\text { Road } \\
\text { Traffic } \\
\text { accident } \\
(\%) \\
\end{array}$ & $\begin{array}{c}\text { Falls } \\
\text { from } \\
\text { height } \\
(\%)\end{array}$ & $\begin{array}{c}\text { Violent } \\
\text { assault } \\
(\%)\end{array}$ & $\begin{array}{c}\text { Firearm } \\
\text { injury } \\
(\%)\end{array}$ & \\
\hline $\begin{array}{l}\text { Nose } \\
\text { (Nasal bone fracture, } \\
\text { soft tissue injury of the } \\
\text { nose without nasal } \\
\text { fracture and traumatic } \\
\text { epistaxis) }\end{array}$ & 39.6 & 25.0 & 27.0 & 6.4 & \\
\hline $\begin{array}{l}\text { Ear } \\
\text { (Otorrhea, injury of } \\
\text { external auditory canal, } \\
\text { bleeding per ear and } \\
\text { Injury or avulsion of the } \\
\text { auricle) }\end{array}$ & 72.0 & 16.0 & 4.0 & 8.0 & 0.007 \\
\hline $\begin{array}{l}\text { Throat \& Neck } \\
\text { Sub-mental firearm inlet, } \\
\text { tear in the soft palate, } \\
\text { and Soft tissue injury of } \\
\text { the neck) }\end{array}$ & 36.8 & 26.3 & 15.8 & 21.1 & \\
\hline $\begin{array}{l}\text { Isolated facial injuries } \\
\text { (Fracture maxilla, } \\
\text { fracture mandible and } \\
\text { multiple facial bones } \\
\text { fracture) }\end{array}$ & 26.3 & 36.8 & 15.8 & 21.1 & \\
\hline
\end{tabular}


Table (4): Medicolegal criteria and results of ENT consultant examination of patients with alleged disabilities in association of past ORL injuries (from 2014 through 2017).

\section{Character}

$\begin{array}{cc}\text { Cases } & \text { Percent } \\ \mathbf{n}=60 & (\%)\end{array}$

Alleged mechanism of ORL injuries

- Violent assault

- Occupational injury

- Medical Error and Medical Responsibility

- Road traffic accident

(\%)

Clinical findings according to the ENT consultant's examination

- Conductive Deafness

- Sensorineural loss of hearing

- Nasal deformity (depressed or deviated nasal bridge)

- Healed old ear drum tear

- No abnormal clinical findings

$10 \quad 16.7$

Outcome of alleged ORL injuries

- True allegation

$13 \quad 21.7$

- False allegation

$40 \quad 66.6$

- Non confirmed allegation

7

11.7

Table (5): revealed a significant relationship $p$ value $=(0.001)$ of alleged long-term ORL injuriesassociated complications and deduced outcome according to ENT consultancy examination. False allegation was observed in all cases with conductive deafness (i.e. due to other cause than claimed), in $70 \%$ of healed ear drum cases, and $63.4 \%$ of sensori-neural deafness cases.

True allegations, however, was the outcome in $>$ half of patients presented with nasal deformity (63.3\%), one fifth in healed ear drum tear cases, and a nearly similar percent in sensori-neural deafness cases. Furthermore, nonconfirmed category was mostly associated with nearly one fifth of cases that experienced sensori-neural deafness (18.3\%). 
Table (5): Relationship of Long-term outcomes of ORL injuries and Outcome of alleged ORL injuries according to Medico-Legal Consultation

\begin{tabular}{|c|c|c|c|c|}
\hline \multirow{2}{*}{$\begin{array}{c}\text { Long term } \\
\text { outcome of ORL } \\
\text { injuries }\end{array}$} & \multicolumn{3}{|c|}{$\begin{array}{c}\text { Outcome of alleged complications according to } \\
\text { Medico-Legal Consultation }\end{array}$} & \multirow{2}{*}{$X^{2} p$-value } \\
\hline & $\begin{array}{l}\text { True } \\
\text { allegations } \\
\quad(\%)\end{array}$ & $\begin{array}{c}\text { False } \\
\text { allegations (\%) }\end{array}$ & $\begin{array}{l}\text { Non-confirmed } \\
\text { allegations }(\%)\end{array}$ & \\
\hline Conductive deafness & --- & 100 & --- & \\
\hline $\begin{array}{l}\text { Sensory neural loss of } \\
\text { hearing }\end{array}$ & 18.3 & 63.4 & 18.3 & $<0.001 * *$ \\
\hline $\begin{array}{c}\text { Nasal deformity } \\
\text { (depressed nasal } \\
\text { bridge) }\end{array}$ & 63.3 & 36.7 & --- & \\
\hline $\begin{array}{l}\text { Healed old ear drum } \\
\text { tear }\end{array}$ & 20 & 70 & 10 & \\
\hline Normal cases & --- & 90 & 10 & \\
\hline
\end{tabular}

\section{DISCUSSION}

Ear, nose and throat traumatic emergencies are commonly encountered in clinical practice and constitute a significant cause of morbidity and mortality resulting in increased costs of care and different degrees of physical, functional and cosmetic disfigurement (Kitcher et al., 2007; Aremu et al., 2011). The present work emphasized that the highest incidence of these injuries was in the young adult group which were similar to the results of Orji (2009). This could be explained by the fact that this age is the most active and assertive age group and can be involved in fights with less secure agents. ENT injuries occur in all age groups; however, mechanisms and causes differ between children and adults (Arif et al., 2006). Male predominance in the present study was similar to different previous research findings (Lebeau et al., 2006;
Bouguila et al., 2008a; Abbas et al., 2009; Keita et al., 2010; Hashim and Iqbal, 2011; Onotai and Ibekwe, 2010; Bhatia and Tuli, 2017). The fact that males are more physically active than their female counterparts and engaged in high risk activities, thus being more vulnerable to trauma, can explain the observed gender differential susceptibility of ORL injuries. Additionally, cultural and social taboos of other Arabian countries, where males are the sole earners of households and females are predominantly bounded to house, may be a contributing factor (Abdullah et al., 2013 and EI Shehaby et al.,2018). In contrast, a UK-based study reported equal male to female ratio. Such variation can be explained through a more liberal and developed social culture alongside equal work opportunities and exposure of both genders in that area (Yates et al., 
2006). Most patients in the present study came from urban areas like Assiut City. A Similar observation was also reported by Aremu and colleagues (2011) but variant from Singhai and other researchers (2017), who reported that most patients were from rural areas. The reason for the high number of patients residing in urban areas in this study may be attributed to a high incidence of road traffic accidents which is common in cities compared with rural areas.

Causes or mechanisms of ORL injuries have been reported to vary with age and geographic distribution (Matilda et al., 2012). In adults, common etiologies of ENT injuries, across the world, are road traffic accidents (RTA), assaults, falls and sports, that differ completely from children in which foreign body impaction in the ear, nose and throat remains the commonest to occur with serious complications (Figueriedo et al., 2008).

Types of injuries in the subSaharan region are different from those in developed countries. Arif and Saatea (2006) reported that RTAs is the leading cause of ENT injuries in developing countries, while interpersonal violence is the leading cause in developed ones. Road traffic accidents represented the main mechanism of ORL injuries in the current study followed by violent assaults; other causes were falls from heights and firearm injuries. Those etiologies were parallel to those identified in other developing countries like Pakistan (Khatri et al., 2016), Nigeria (Olajide et al., 2017) and India (Singhai et al., 2017; Adegbiji et al., 2018).

High RTA rate is due to nonobservance and lack of strict enforcement of speed limits, non-use of seatbelts and negligence of wearing protective crash helmets, bad road repairs, poorly maintained vehicles with minimal safety features and increased use of motorcycles (Fasola et al., 2003). Some of the previously identified risk factors for ORL injuries differed from the current results where daily life activities were the main causative factor in Austria (Gassner et al., 2003), and foreign body impact (Gilyoma and Chalya, 2013) in Tanzania.

Blunt trauma was responsible for the majority of cases; matching those of Gilyoma and Chalya (2013) which is one of the most common forms encountered in a variety of scenarios such as transportation fatalities, violent assaults, jumping or falling from heights, blast injuries, being struck by firm objects (Kranioti, 2015). The midface was involved in more than half of injuries $(55 \%)$ in the current study involving nasal and maxillofacial injuries; the nose was the commonest part recorded being affected in nearly half of cases followed by the ear which was in agreement with other researches (Arif et al., 2006; Afolabi et al., 2010; Olajide et al., 2017). However, a contrasting study of Gilyoma and Chalya (2013) revealed the ear as the most common region involved in facial injuries or isolated maxillofacial fractures in another research (Bhatia and Tuli, 2017).

Nasal bone fracture was the commonest pattern of all ORL injuries and even among all reported nasal injuries, paralleling to Renner (1991) and Fernandes (2004) that can be explained by the fact that the nose is in a prominent position in the face and less force is required to cause a nasal fracture than other facial fractures. Nasal fracture frequently results from 
blunt trauma to the midface. Other studies delineated other nasal patterns of injuries, where traumatic epistaxis in Nigerians (Olajide et al., 2017) or mandibular fracture in Indians (Yojana et al., 2012) were the commonest types. Meanwhile, Zargar and colleagues (2004) confirmed an equal incidence of mandibular and nasal fractures in Tehran. Nasal fractures are of medicolegal implications in forensic practice as well as in medical work; they are often unrecognized and untreated at the time of injury. Nasal bones and cartilage provide cosmetic and structural support for the midface and improper evaluation and treatment may predispose to nasal deformity. Second importance lies in the frequency of nasal fractures with minor unexpected facial trauma.

Isolated ENT injuries represented the majority of cases with one fifth of casualties had associated injuries; the commonest of which were extradural hemorrhage, cerebral concussion, musculoskeletal injuries and facial palsy. This finding was more or less similar to Adebayo and other researchers (2003). Associated injuries are common as well as there is tendency of the nose, ear, and throat to get involved in most injuries of the head and neck because of the prominence of the face and highenergy facial skeleton traumas (such as RTA) caused more frequent cervical spine injury in comparison to lowenergy mechanisms (Deliverska, 2014).

Generally, the outcome in this study was satisfactory as $>90 \% \mathrm{t}$ of patients were treated successfully and discharged with no expected permanent disabilities, and only $1 \%$ mortality rate was reported. This result was parallel to Gilyoma and Chalya (2013) who reported a mortality rate of $1.3 \%$ while others reported no mortalities at all (Olajide et al., 2017). This might be due to early presentation and proper management and the majority of cases have had simple wounds.

Injuries are caused by intentional (occurring with purposeful intent and include homicide, suicide, domestic violence, bias-related violence and firearms) and unintentional (occurring without purposeful intent, and are the leading cause of death and disability among all age groups regardless of gender, race or economic status; and it is also the leading killer of middle aged victims) (Jagannatha et al.,2010). Non-intentional manner of trauma was the main reported manner of ORL injuries in the form of RTAs followed by falls from height; this was a common observation in most studies with similar type of ORL injuries (Khatri et al., 2016; Olajide et al., 2017; Singhai et al., 2017). Falls from height are considered a persistent hazard met in all communities and occupational locations. It is frequently encountered in accidents, suicides and rarely in homicides (Hagga et al., 2016). Extent of injuries due to fall from height varies depending on the falling distance, composition of the impact surface, objects encountered during the falling process, rate of deceleration, intermediate, position of the body when landing, individual factors such as body weight, preexisting disease and also age of the person (child, adult, and elderly). Craniocerebral trauma (head injury) is the primary cause of mortality among all skeletal injuries. Among soft tissue injuries reported, injury to brain followed by liver, lung and spleen were common (Jagannatha et al., 2010).

Retrospective analysis of ENT consultants' reports for alleged long 
run complications following ORL injuries in the period from 2014-2017, was investigated because death due to injury is only part of the picture; but the consequences of non-fatal injuries is more important. These range from temporary pain to long-term disability, permanent infirmity and a diminished quality of life. Furthermore, economic impact of such injuries includes costs associated with medical treatment and lost productivity (Frederick et al., 2000).

Long run complications of ORL injured patients who were referred from the Egyptian Medicolegal Authorities in the current study, were mostly the middle-aged men who inhabited urban areas and employed as manual workers with low to middle level of education. Those patients alleged violent assaults and fights as the main cause of their ORL associated disabilities. Those demographic features were in line with a study of Shetty and coinvestigators (2003), on the psychological sequel of orofacial injuries. Alleged violent assaults as a contributing factor to long-term ORL injuries related complications was the main claim in the present study. Victims were searching for their legal and financial compensations due to their suffering following ORL injuries.

Permanent infirmity as a common sequel of injury is essentially a legal as well as a medical concept. The ENT physician must have some understanding of legal theories and practices behind compensation for injuries in order to save the rights of the patient and the public (Frederick et al., 2000).

ENT consultants should not be fooled by claims of victims of violent assaults. Past history of trauma, proper medical and surgical intervention, external examination and investigations of current alleged disabilities should be taken into consideration to establish proof for the true allegation and saves the legal and civil rights of the suffering victim (Kretlow et al., 2010).

Commonest complication reported in the current study was the sensorineural deafness followed by the nasal deformity. This may be explained as ORL injuries are frequently associated with head injuries and temporal bone fracture that leads to such complications. Additionally, reported nasal deformities may lead to loss of ethnic form and function of the nose and maybe the facial shape as well (Verbruggen and Halewyck, 2016). Notably, most complainants were malingering (false allegations). Nonconfirmed category of presented claimants was due to the inability to adequately determine whether those complications were related to previous ORL trauma or overlapping pathological state or even old age atrophic changes. The latter category was mostly reported in association with sensori-neural hearing loss. However, to the authors' knowledge, very few pieces of literature had addressed such litigation associated ORL complications worldwide. Here in Egypt, medicolegal authorities handling such alleged disabilities refer them to the ENT consultant for confirming or denying trauma related infirmities. Then, the forensic physician decides the percent of the fixed infirmities if proved according to the nationally established infirmity tables (Abdellatif, 2016).

\section{CONCLUSION}

The present study addressed a differential pattern of prospectively presented ORL injuries, and retrospective associated disabilities or long-term complications. Nasal injuries in young adults with RTA as a main 
contributing etiology, versus auditory complications of middle-aged men, claiming violent assaults as a main cause of associated ORL disabilities, were emphasized.

\section{RECOMMENDATIONS}

Early careful diagnoses of ORL injuries and proper treatment can prevent possible deformity and permanent infirmity. Proper legislation, implementation of traffic rules and imminent roads infrastructure can prevent road traffic accidents and subsequently ORL injuries.

Careful examination and thorough investigations with a good knowledge of the legal implications of ORL associated complications can exclude fabricated claims. The medico legal physician must have some understanding of legal theories and practices behind compensation for injuries in order to reform this role for the safe the rights of the patient and the public

\section{REFERENCES}

Abbas, Iram, Muhammad Fayyaz, Irfan Shah, Muhammad Ayub Khan, Sadia Haleema Qazi, Nadia Munir, Ayesha Bibi, and Masroor Abbasi. 2009. "Demographic Distribution of Maxillofacial Fractures in Ayub Teaching Hospital: 7-Year Review." Journal of Ayub Medical College, Abbottabad: JAMC 21 (2): 110-12. http://www.ncbi.nlm.nih.gov/pub $\mathrm{med} / 20524484$.

Abdellatif, Magda. 2016. "Injuries of Ear, Nose and Throat." In Arabic Encyclopedia in Forensic Medicine, edited by Prof. Aly hussein and forensic Medicine academic staff members, First edit, 325-56. Fairy Color, Cairo, Egypt. Abdullah, Walid A, Khaled AlMutairi, Yasser Al-Ali, Abdullah Al-Soghier, and Abdullah Al-Shnwani. 2013. "Patterns and Etiology of Maxillofacial Fractures in Riyadh City, Saudi Arabia." The Saudi Dental Journal 25 (1): 33-38. https://doi.org/10.1016/j.sdentj.20 12.10.004.

Adebayo, E.T, O.S Ajike, and E.O Adekeye. 2003. "Analysis of the Pattern of Maxillofacial Fractures in Kaduna, Nigeria." British Journal of Oral and Maxillofacial Surgery $41 \quad$ (6): $\quad 396-$ 400.https://doi.org/10.1016/ S0266-4356(03)00165-7.

Adegbiji, W A., T G. Olajide, O A. Olajuyin, F. Olatoke, and $\mathrm{C} C$. Nwawolo. 2018. "Pattern of Presentation of Ear, Nose, Throat, Head and Neck Injury in a Developing Country." Research Journal of Health Sciences 6 (1): 3-12.

Afolabi, O A, B S Alabi, Afolabi O.A., and B S Alabi. 2010. "Aetiological Profile of Nasal Trauma in Ilorin North-Central Nigeria." Nigerian Journal Of Medicine: Journal Of The National Association Of Resident Doctors Of

Nigeria.https://doi.org/10.4314/nj m.v19i4.61955.

Aremu, S. K., B. S. Alabi, S. SegunBusari, and W. Omotoso. 2011. "Audit of Pediatric ENT Injuries." International Journal of Biomedical Science.

Arif, R K., U. Naseem, U. Inayat, E D. Shah, and S K. Noor. 2006. "Causes and Complications of Ear, Nose and Throat Injuries in Children. A Study of 80 Cases." J Med Sc 14 (1): 57-59. 
Bhatia, Abhijeet, and Isha Tuli. 2017. Analysis of Ear, Nose and Throat Injuries Reporting to a Tertiary Care Hospital in Sikkim. Al Ameen J Med Sci. Vol. 10.

Bouguila, J., I. Zairi, RH. Khonsari, Y. Jablaoui, M. Hellali, and A. Adouani. 2008a. "Epidemiology of Maxillofacial Traumatology in Tunis." Revue de Stomatologie et de Chirurgie Maxillo-Faciale. 109 (6): 353-57.

Bouguila, J, I Zairi, R.H. Khonsari, Y Jablaoui, M Hellali, and A Adouani. 2008b. "Épidémiologie de La Traumatologie Maxillofaciale à Tunis." Revue de Stomatologie et de Chirurgie Maxillo-Faciale 109 (6): 353-57. https://doi.org/10.1016/j.stomax.2 008.04.009.

Deliverska E. 2014. "Occurrence and Types of Associated Injuries in Patients with Maxillofacial Fractures." Int J Sci Res 3 (12): 85-97.

El Shehaby D, Saleh M, Shahine M, Sayed MM. 2018 Did January 25th Egyptian Revolution Change the Medico-Legal Pattern and the Trend of Hospitalized Injuries in Upper Egypt? A retrospective study. The Egyptian Journal of Forensic Sciences and Applied Toxicology;18(4):15-27,

Doi:10.21608/ejfsat.2018.4609.10 19

Fasola, A.Olubayo, Ebenezer A. Nyako, Ambrose E. Obiechina, and Juwon T. Arotiba. 2003. "Trends in the Characteristics of Maxillofacial Fractures in Nigeria." Journal of Oral and Maxillofacial Surgery 61 (10): 1140

43.https://doi.org/10.1016/S0278 2391(03)00671-2.

Fernandes, SV. 2004. "Nasal Fractures: The Taming of the
Shrewd." The Laryngoscope 114 (3): 587-92.

Figueriedo, RR, AA Azevedo, AO Kos, and S Tomita. 2008. "Complications of Ear, Nose and Throat Foreign Bodies." Braz J Otorhinolaryngol 74: 7-15.

Frederick, Katrina, Elizabeth Bixby, Marie Noelle Orzel, Sarah Stewart-Brown, and Keith Willett. 2000. "An Evaluation of the Effectiveness of the Injury Minimization Programme for Schools (IMPS)." Injury Prevention. https://doi.org/10.1136/ip.6.2.92.

Gali, Rajasekhar, SathyaKumar Devireddy, RV Kishore Kumar, SridharReddy Kanubaddy, Chaithanyaa Nemaly, and Mohammed Akheel. 2015. "Faciomaxillary Fractures in a Semi-Urban South Indian Teaching Hospital: A Retrospective Analysis of 638 Cases." Contemporary Clinical Dentistry.https://doi.org/10.4103/0 976-237X.169847.

Gassner, R, T Tuli, O Hächl, A Rudisch, and $H$ Ulmer. 2003. "Cranio-Maxillofacial Trauma: A 10 Year Review of 9,543 Cases with 21,067 Injuries." J Craniomaxillofac Surg 31 (1): 5161.

Gilyoma, J M., and $\mathbf{P}$ L. Chalya. 2013. "Ear, Nose and Throat Injuries at Bugando Medical Centre in Northwestern Tanzania: A Five-Year Prospective Review of 456 Cases." BMC Ear, Nose, and Throat Disorders 13(March):4.https://doi.org/10.118 6/1472-6815-13-4.

Hagga, G O., S. Zamzam, A A. Sharaf Eldin, and $G A$. Madboly. 2016. "Pattern of Fatal Injuries of Fall from Height at Great Cairo: A Retrospective 
Analytical Study (2009 - 2013)." Egypt. J.Foren. Sci. Appli. Toxicol 16 (2): 97-116.

Hashim, Hasnah, and Syed Iqbal. 2011. "Motorcycle Accident Is the Main Cause of Maxillofacial Injuries in the Penang Mainland, Malaysia." Dental Traumatology 27

(1):

19-22.

https://doi.org/10.1111/j.1600-

9657.2010.00958.x.

Jagannatha, SR, MV Kumar, TN Kumar, $K$ Ananda, and VT Venkatesha. 2010. "Injuries Due to Fall from Height-A Retrospective Study." Journal of Forensic Medicine and Toxicology 27 (1): 47-50.

Keita, M, K Doumbia, M Diani, M Diallo, M Coulibaly, S K Timbo, and $M$ Ag Mohamed. 2010. "Head and neck injuries: 184 cases in Mali." Medecine tropicale: revue du corps de sante colonial 70 (2): 172-74. http://dx.doi.org/.

Khatri, D K., M I. Rao, and M. Ali. 2016. "Pattern of Injuries Regarding Ear, Nose, Throat \& Head \& Neck in Patients Presenting in Accident \& Emergency Department." Pakistan Journal of Surgery.

Kitcher, E d., A. Jangu, and K. Baidoo. 2007. "Emergency Ear, Nose and Throat Admissions at the Korle-Bu Teaching Hospital." Ghana Medical Journal 41 (1): 911.

http://www.ncbi.nlm.nih.gov/pub $\mathrm{med} / 17622332$.

Kranioti, Elena. 2015. "Forensic Investigation of Cranial Injuries Due to Blunt Force Trauma: Current Best Practice." Research and Reports in Forensic Medical Science, October, 25. https://doi.org/10.2147/RRFMS. S70423.
Kretlow, J D., A J. McKnight, and S A. Izaddoost. 2010. "Facial Soft Tissue Trauma." Seminars in Plastic Surgery 24(4):34856.https://doi.org/10.1055/s- 00301269764.

Lebeau, J, V Kanku, F Duroure, B Morand, $H$ Sadek, and B Raphaël. 2006. "[Facial injuries treated in the Grenoble University Hospital. Epidemiological analysis of 961 patients managed in one year]." Revue de stomatologie et de chirurgie maxillo-faciale 107 (1): 23-29. https://doi.org/10.1016/s00351768(06)76977-7.

Matilda, I., O. Lucky, and N. Chibuike. 2012. "Ear, Nose and Throat Injuries in a Tertiary Institution in Niger Delta Region Nigeria." J Med Res Prac 1: 5962.

Olajide, T G., O E. Gabriel, $\mathrm{S}$ M. Agboola, and O E. Fisch. 2017. "Patterns of Ear, Nose and Throat Injuries in Ido Ekiti, Nigeria." Res J Ear Nose Throat 1 (1): 1-5.

Onotai, L.O, and U Ibekwe. 2010. "The Pattern of CutThroat Injuries in the University of Port-Harcout Teaching Hospital, Portharcourt." Nigerian Journal of Medicine 19 (3): 264-66.

Orji, F T. 2009. "Non-Explosive Blast Injury of the Tympanic Membrane in Umuahia, Nigeria." Nigerian Journal of Medicine: Journal of the National Association of Resident Doctors of Nigeria 18 (4): 365-69. http://www.ncbi.nlm.nih.gov/pub $\mathrm{med} / 20120138$.

Pilija, V, M Buljčik, M Mihalj, S Savović, and $G$ Stojiljković. 2005. "Classification and Qualification of Nose Injuries: Clinical and Forensic Aspects." 
Medicinski Pregled 58 (1-2): 3336.

Piorkowski, J D. 2001. "Medical Testimony and the Expert Witness." In Legal Medicine, edited by American College of Legal Medicine Textbook Committee, fifth, 93-107. St Louis, Mosby Inc;.

Renner, G J. 1991. "Management of Nasal Fractures." Otolaryngologic Clinics of North America 24 (1): 195-

213.http://europepmc.org/abstract/ MED/2027698.

Sanbar, S S. 2007. Legal Medicine. Elsevier Health Sciences.

Shetty, Vivek, Shirley Glynn, and Karin Elliott Brown. 2003. "Psychosocial Sequelae and Correlates of Orofacial Injury." Dental Clinics of North America $47 \quad$ (1): 141-57. https://doi.org/10.1016/S00118532(02)00059-9.

Singhai, J, R Nigam, and A K Jain. 2017. "The Demographic Study of Otorhinolaryngological Trauma Among Patients with Head and Neck Trauma and Their Management in a Tertiary Care Centre." Indian Journal of Otolaryngology and Head \& Neck Surgery 70 (2): 1-7.

Verbruggen, K., and S. Halewyck. 2016. "Long-Term Complications after Facial Trauma: Literature Review." B-ENT 12 (26/2): 4758.
Yates, P J, W H Williams, A Harris, A Round, and R Jenkins. 2006. "An Epidemiological Study of Head Injuries in a UK Population Attending an Emergency Department." Journal of Neurology, Neurosurgery, and Psychiatry 77 (5): 699-701.

Wasfy, Ismail A, Ehab Ia Wasfy, Tarek A. Aly, and Alaa A. AbdElsayed. 2009. "Ophthalmic Medicolegal Cases in Upper Egypt." International Archives of Medicine 2 (1): 1. https://doi.org/10.1186/1755-

7682-2-https://doi.org/10.1136/ jnnp.2005.081901.

Yojana, Sharma, Kanishk Mehta, and Mishra Girish. 2012. "Epidemiological Profile of Otorhinolaryngological

Emergencies at a Medical College, in Rural Area of Gujarat." Indian Journal of Otolaryngology and Head \& Neck Surgery 64 (3): 218-24. https://doi.org/10.1007/s12070011-0293-8.

Zargar, M., A. Khaji, M. Karbakhsh, and M R. Zarei. 2004. "Epidemiology Study of Facial Injuries during a 13 Month of Trauma Registry in Tehran." Indian J Med Sci 58 (3): 109-14. 


\section{الملخص العربي}

الجوانب الطبية الشرعية لإصابات الأذن والأنف والحنجرة والوجه والرقبه في صعيد مصر:

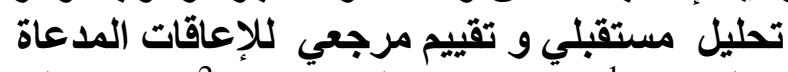

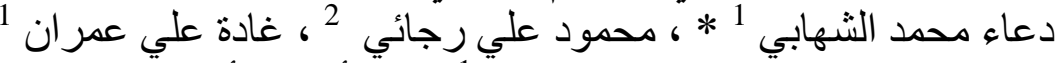

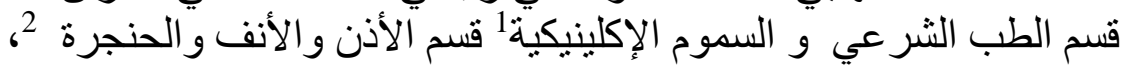
كلية الطب البشري، جامعة أسيوط ، مصر الاذن والان

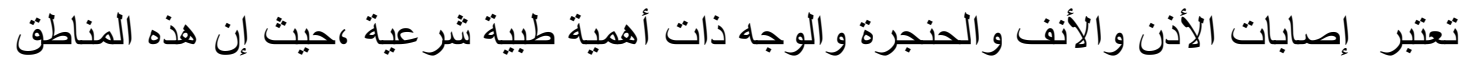

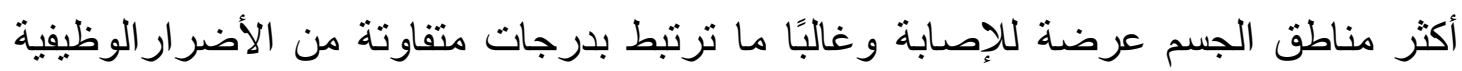

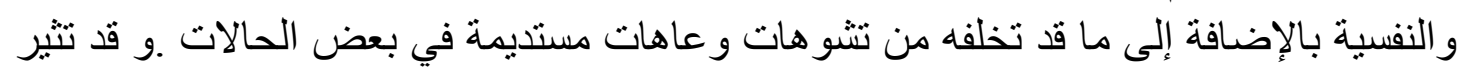

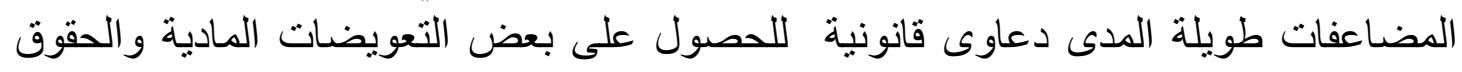

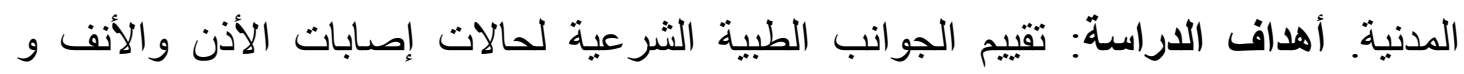

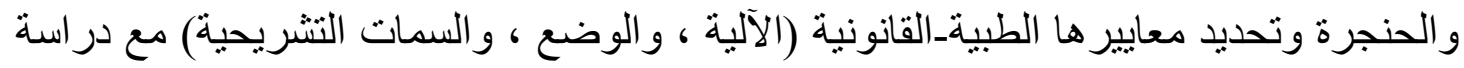

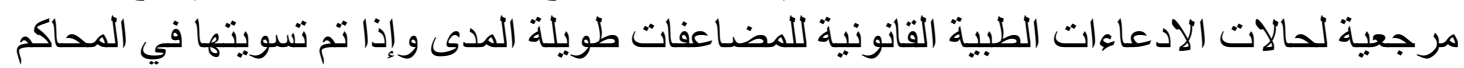

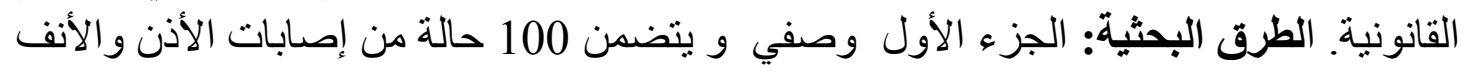

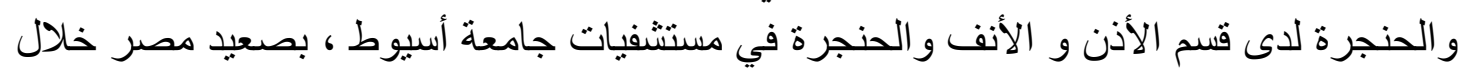

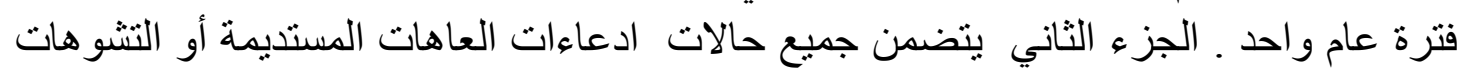

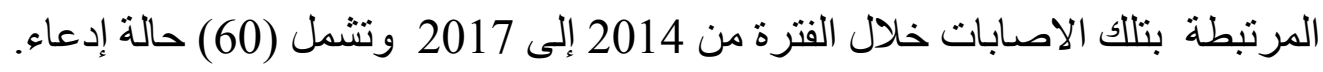
النتائج البحثية : ـ وقد اوضحت الدراسة من خلال نتائجها أن متوسط العمر لحالات الإصنابات

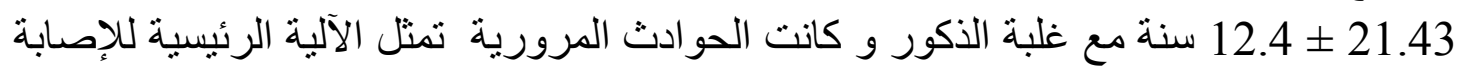

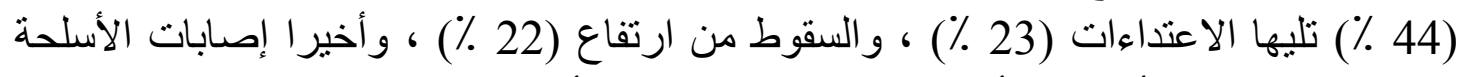

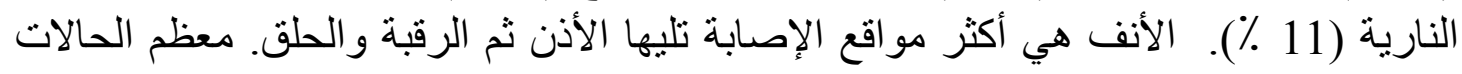

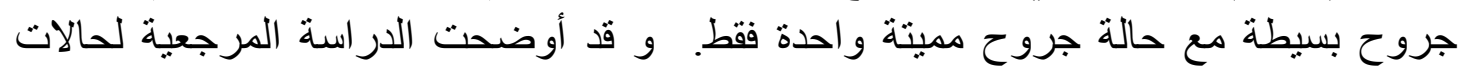

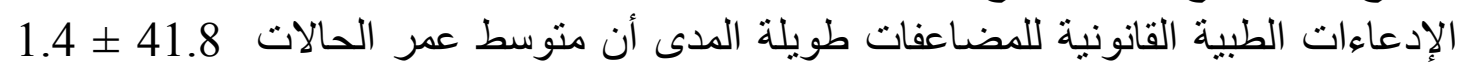

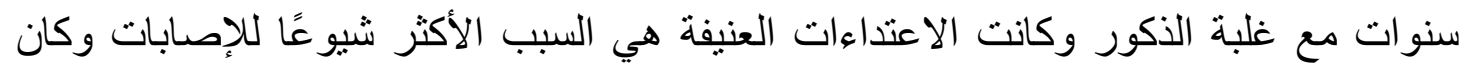

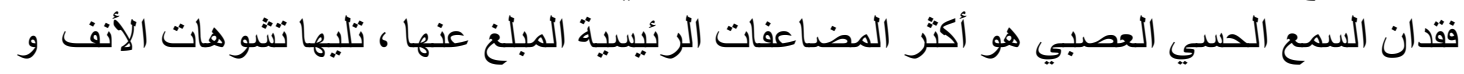
كانت ادعاءات المرضى الغير صحيحة أعلى نسبة من الادعاءات الحقيقية خاصة في حالات تشوه الأنف. ت أدعات. 